IZA DP No. 6427

Active Inclusion of Immigrants in Poland

Maciej Duszczyk

Marek Góra

March 2012

Forschungsinstitut zur Zukunft der Arbeit Institute for the Study of Labor 


\title{
Active Inclusion of Immigrants in Poland
}

\author{
Maciej Duszczyk \\ IPS, University of Warsaw \\ Marek Góra \\ Warsaw School of Economics \\ and IZA
}

\section{Discussion Paper No. 6427 \\ March 2012}

\author{
IZA \\ P.O. Box 7240 \\ 53072 Bonn \\ Germany \\ Phone: +49-228-3894-0 \\ Fax: +49-228-3894-180 \\ E-mail: iza@iza.org
}

\begin{abstract}
Any opinions expressed here are those of the author(s) and not those of IZA. Research published in this series may include views on policy, but the institute itself takes no institutional policy positions.

The Institute for the Study of Labor (IZA) in Bonn is a local and virtual international research center and a place of communication between science, politics and business. IZA is an independent nonprofit organization supported by Deutsche Post Foundation. The center is associated with the University of Bonn and offers a stimulating research environment through its international network, workshops and conferences, data service, project support, research visits and doctoral program. IZA engages in (i) original and internationally competitive research in all fields of labor economics, (ii) development of policy concepts, and (iii) dissemination of research results and concepts to the interested public.
\end{abstract}

IZA Discussion Papers often represent preliminary work and are circulated to encourage discussion. Citation of such a paper should account for its provisional character. A revised version may be available directly from the author. 


\section{ABSTRACT}

\section{Active Inclusion of Immigrants in Poland ${ }^{*}$}

Poland has traditionally been treated as an emigration country. Since recently Poland has been changing into an emigration-immigration country. The latter, namely immigration, was boosted by the European Union membership and by stable and strong growth of the country. In the last years, immigrants have started to play an important role in the Polish labour market, which creates an additional challenge for the institutional structure. At the same time the institutional framework for receiving immigrants, especially integration policy, has not been fully developed yet. It is addressed only to refugees and is provided mostly by NGOs who run various integration programmes (most often focused on providing language courses). Public expenditure on integration policies has recently increased. However, data on immigrants, integration in immigration policy and also its analysis are still scarce. In this paper we try to present and discuss the available information on immigration to Poland and instruments of integration policy in the context of the existing institutional framework. We propose also recommendations for the pre-integration and integration policy in Poland. The goal of the paper is modest since it is hardly possible to apply more sophisticated methods given the limited availability of information.

JEL Classification: J61, J68, Y80

Keywords: immigrants, integration policy, active inclusion

Corresponding author:

Marek Góra

Warsaw School of Economics

Aleja Niepodleglosci 162

02-554 Warszawa

Poland

E-mail: Marek.Gora@sgh.waw.pl

\footnotetext{
* Revised version of a study prepared for IZA Research Report No. 43 ("Study on Active Inclusion of Migrants").
} 


\section{Contents}

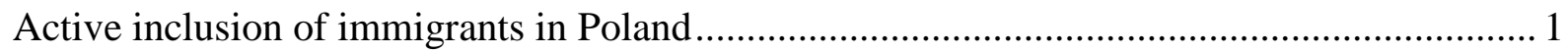

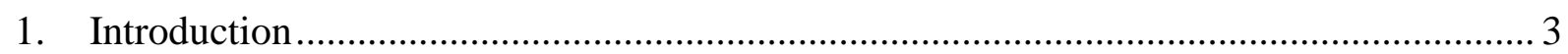

2. The scale of immigration to Poland in the 21 st century. ................................................ 3

2.1. TRENDS OF IMMIGRATION TO POLAND. .....................................................

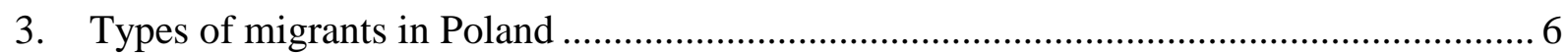

3.1. MigRANTS FROM THE MEMBER STATES OF THE EUROPEAN ECONOMIC AREA AND

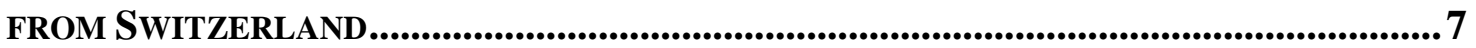

3.2. MIGRANTS FROM OECD MEMBER STATES (EXCEPT CITIZENS OF THE EEA AND

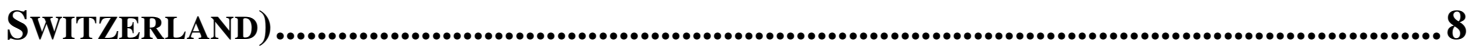

3.3. NON-OECD NATIONALS OBTAINING WORK PERMIT ........................................8

3.4. Citizens OF UKRAINe, RuSSia AND Belarus UNDERTAKING TEMPORARY EMPLOYMENT IN POLAND. ...................................................................................9

3.5. REGIONAL DIVERSIFICATION OF EMPLOYMENT OF IMMIGRANTS IN POLAND. 11

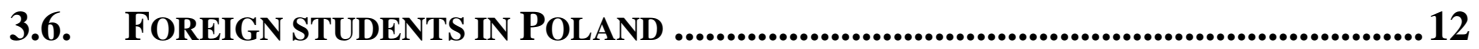

4. Access of immigrants to the Polish welfare system................................................... 12

4.1. INTERACTION BETWEEN MIGRATION POLICY AND SOCIAL ASSISTANCE...........12

4.2. THE LEGAL DIMENSION OF THE INTEgRATION OF IMMIGRANTS IN POLAND... 13

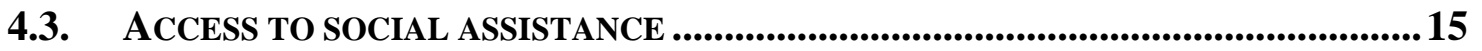

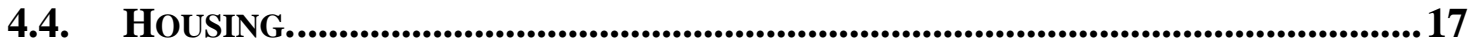

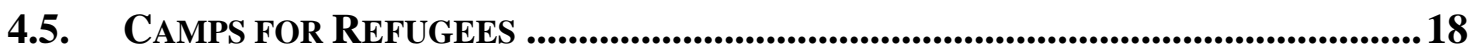

4.6. INDIVIDUAL PROGRAMS OF INTEGRATION FOR REFUGEES. ............................19

4.7. ACCESS OF IMMIGRANTS TO THE POLISH EDUCATION SYSTEM. ......................... 24

4.8. PROgRAMS OF NGOS FOR REFUgEeS AND FOR IMMIGRANTS WITH TOLERATED

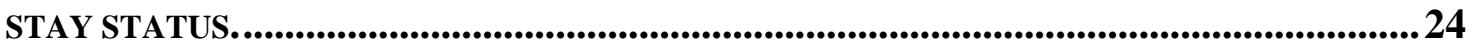

4.9. EUROPEAN FUND FOR THE INTEGRATION OF NON-EU NATIONALS.................227

4.10. EUROPEAN FUND FOR REFUGEES (2008-2013) ...........................................28

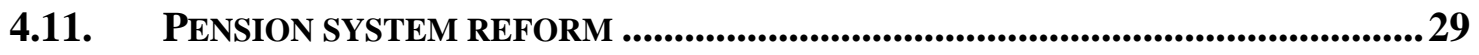

4.12. FOREIGNERS AND NATIVES IN THE WELFARE SYSTEM .................................30

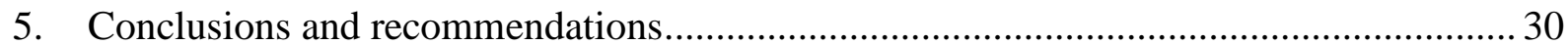

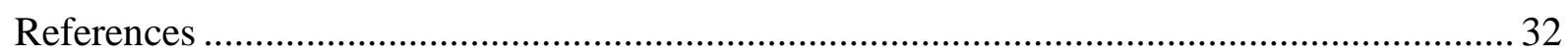




\section{Introduction}

This study analyses welfare use by migrants and by native citizens in Poland. We use available data to assess the country-specific issues related to welfare consequences stemming from the presence of immigrants. They are still not very numerous and their presence does not create substantial challenges for the welfare system of the country. Traditionally, it is Polish citizens who have emigrated abroad, while immigration to Poland is a new phenomenon, which has not yet been internalised by the public. Moreover, public institutions including social security, the labour market and social assistance are poorly prepared to operate in the new situation in which Poland itself as well as Poland as a member state of the European Union is increasingly attractive to foreign nationals.

In the study we review and analyse the available data and institutional information about the welfare system, how it affects immigrants and their labour market status, housing markets and other possible factors. We also present - to the extent possible given data limitations - differences in the observed rate of welfare use among immigrants as compared to the native population. We analyse immigrant status (foreign-born, citizenship, second generation); migration-specific adjustment effects such as language problems, discrimination, network effects, non-portability of welfare entitlements; and reduced wages as a result, for example, of being excluded from some job categories or sectors. In our analysis we do not apply sophisticated models of migration since the data available are insufficient for that.

Although the scale of immigration to Poland is still relatively small, we point out tentative policy conclusions and recommendations. ${ }^{1}$

\section{The scale of immigration to Poland in the 21st century.}

Poland transforms from a typical emigration state into an emigration-immigration state, i.e. a model characteristic to the EU member states. ${ }^{2}$ Poland's accession to the European Union caused not only a significant outflow of Poles to other member

\footnotetext{
${ }^{1}$ Return migration of Polish workers coming back after temporal emigration goes beyond the scope of this paper since it addresses a different institutional framework and a different set of economic phenomena.

${ }^{2}$ For more details see: A. Górny, I. Grabowska-Lusińska, M. Lesińska, M. Okólski (eds.) Immigration to Poland, Centre of Migration Research, Scholar, Warsaw 2010.
} 
states, but also a growth of interest in obtaining the right to stay and be employed in Poland. It must be pointed out, however, that Poland is characterised by a negative balance of foreign migration. ${ }^{3}$ This makes Poland stand out against the majority of the EU member states. Furthermore, the attention of both decision-makers and public opinion is focused more on Poles leaving to undertake employment in other EU member states rather than on third-country nationals coming to Poland.

Unfortunately, a precise analysis of both the scale and flows of migration to Poland is hindered due to a lack of reliable and comparable sources concerning immigration. Information on foreign nationals working in Poland is fragmentary, dispersed and indirect. One part covers immigration resources, another part deals with immigration flows. Moreover, the existing data collections frequently reflect the legislative and institutional changes that have taken place in recent years. Therefore, the data presented below must be treated as uncertain due to the lack of reliable statistics. Nevertheless, the data available are adequate for an analysis of the immigration trends of various categories of foreign nationals to Poland.

\subsection{Trends of immigration to Poland.}

An analysis of the official statistical data (data from the Ministry of Labour and Social Policy, the Ministry of Internal Affairs, the Central Statistical Office and the Office for Foreigners) regarding the issue of work permits in Poland shows that recently the scale of registered immigration has been increasing. However, exact figures regarding the number citizens of other states coming to Poland to settle/work are unknown. The present volume of official long-term immigration can be estimated at approximately 25, $000-40,000$ persons annually, including approximately 20,000 citizens of other European Union states.

\footnotetext{
${ }^{3}$ Information about size and directions of emigration from Poland in the years 2004-2010, GUS, Warsaw 2010
} 


\begin{tabular}{|l|l|}
\hline $\begin{array}{l}\text { Work } \\
\text { (90\% for more than } 1 \text { year) }\end{array}$ & permits \\
\hline 2007 & 12,153 \\
\hline 2008 & 18,022 \\
\hline 2009 & 29,340 \\
\hline 2010 & 37,121 \\
\hline EU citizens - ca. 20, 000 (do not need work permits) \\
\hline Source: the Ministry of Labour and Social Policy
\end{tabular}

The Office for Foreigners provided statistics of various data on issued temporary stay permits of third-country nationals staying in Poland. These data suggest that the number of residence permits issued to non-EU citizens is relatively constant in time. However, the group of "others" ignores those European countries that acceded to the European Communities in 2004 and 2007, allows us to discern a subtle growth trend. In other words, the phenomenon of registered immigration to Poland is most likely intensifying, but rather in a slow manner.

Data provided by the Ministry of the Interior show nearly 100,000 foreign nationals had valid residence cards at the end of 2010. The figure was higher by 4,506 persons compared to 2009, while in relation to 2008 it was higher by 19,314 people. Despite immigration increase, especially after joining the EU, Poland still has the lowest percentage of immigrants among the member states.

Various statistical data and scientific research attempting to estimate the number of third-country nationals coming to and staying in Poland suggest that the largest group of foreign nationals comprises citizens of Poland's Eastern neighbours, namely: Ukraine, Russia and Belarus. The vast majority come to Poland for employment purposes and their stay can be counted as short-term.. They generally make little 
effort to integrate in Polish society, and usually leave Poland after their employment period elapses.

This group also includes so-called over stayers, i.e. foreign nationals who overstay in Poland unlawfully after the deadline of their legal stay expires. In their case integration measures are most frequently related to legalisation of stay. During their undocumented stay in Poland, apart from support from NGOs, they cannot count on any assistance in the process of integration with Polish society.

It must be pointed out, however, that foreign nationals originating from the states neighbouring Poland do not have serious problems integrating with Polish society due to both cultural similarities and the frequency of bi-national marriages.

Similarly to other states receiving immigrants, Poland has fundamental problems with assessing the scale of undocumented stays. Fragmentary data usually supplied by NGOs and research centres suggest that in Poland there are also approximately 80,000-100,000 Ukrainians, 20,000 Armenians and 25,000 Vietnamese whose stay is undocumented. In their case integration takes a long time and makes it necessary to offer diversified instruments within integration policy.

Thanks to the Amnesty Act which came into force on 1 January 2012 it will be possible to verify data on the undocumented stay of foreign nationals in Poland. The Act enables legalisation of foreign nationals' stay for two years. During that time they will be required to obtain legal residence status, which will enable their further stay in Poland.

\section{Types of migrants in Poland}

Five groups of immigrants can be identified in Poland on the basis of source region. These are foreigners coming from:

- The European Economic Area and Switzerland

- The OECD member states (except for the European Economic Area and Switzerland)

- Poland's Eastern neighbouring countries (Belarus, Ukraine and Russia)

- Far East countries (mostly Vietnam and China)

- Other regions 
Data available on immigrants belonging to these groups differ substantially. Data on the first two groups are available and reliable, while data on migrants belonging to the other three groups are only partial and need to be estimated based on various methods and assumptions.

\subsection{Migrants from the member states of the European Economic Area and from Switzerland}

Despite the transitional period restrictions applied by some EU countries in the area of free movement of workers, as of 1 May 2006 Poland decided to lift restrictions for all citizens of the member states of the European Economic Area and Switzerland on an access to its labour market. Between 1 May 2004, i.e. accession to the European Union, and 1 May 2006 Poland applied a transitional arrangement within the regulations on free movement of workers by opening access to its labour market under rules parallel to those applied by EU-15 states. As a result of lifting the restrictions, Poland does not currently issue work permits for citizens of the EEA member states and Switzerland. Moreover, Poland does not collect detailed statistics on employment of these citizens in Poland. Data collected before the opening of Poland's labour market suggest the scale of immigration from the EEA member states and Switzerland rose following Poland's accession to the European Union. During 2004-2005 there was a visible increase in the number of issued permits. The greatest percentage of positive decisions was given to citizens of the largest EU states: Germany (approx. 50 per cent), France, and the United Kingdom (below 10 per cent each on average). These countries have strong trade and capital links with Poland. According to new regulations, citizens of the EEA member states and Switzerland planning a stay exceeding 3 months are required to register their stay ${ }^{4}$. As a result, approximately 25,000 citizens of the EEA countries and Switzerland registered their stay in Poland between 26 August 2006 and November 2009. 6,405 European Union citizens applied for residence registration in 2010. The largest group constituted 1,771 German citizens. In mid - 2011, the number of EU citizens legally staying in Poland reached cc. 50,000 people.

\footnotetext{
${ }^{4}$ Family members receive so-called residence cards of a family member of EU citizen; the overall number of issued cards is unknown.
} 


\subsection{Migrants from OECD member states (except citizens of the EEA and Switzerland)}

Non-EAA or Swiss nationals are required to obtain work permit and residence permit in Poland. The February 2009 amendment to the Act on Employment Promotion and Labour Market Institutions brought far-reaching liberalisation of the rules governing the issue of work permits. According to the legal provisions currently in force, a work permit is issued to a foreigner on the request of the employer provided that within 7 days (or 14 days in particularly justified cases) the Poviat ${ }^{5}$ Employment Office does not present an unemployed person who satisfies requirements of the employer. In practice, such permits are issued virtually automatically to citizens of the OECD member states. However, only around 10 per cent of the issued permits are for persons from these states. . In the decisive majority their stay in Poland is related to deployment of investments in Poland by their parent company (posted workers). Among citizens of the OECD member states receiving work permits in Poland Americans, Canadians, Turks and Koreans prevail. However, the number of work permits issued to citizens of those states does not exceed 1,000 annually.

It is worth noting there are frequent cases of persons formally posted to Poland who fail to inform Polish authorities about this fact, so from the formal viewpoint they are employed in Poland illegally. However, this mainly concerns occasional employment.

\subsection{Non-OECD nationals obtaining work permit}

According to data available, the vast majority (approx. 80 per cent in 2002, over 85 per cent in 2010) of work permits was issued to citizens of non-EU European states (the former USSR, the Balkan states) and Asian states (mostly China and South-East Asia), with the share of Asian countries constantly rising.

The analysis of data on permits for temporary residence suggests similar conclusions. Immigration is dominated by East European and Asian countries' citizens, who constitute approx. 90 per cent of all residence permits issued to nationals of non-

\footnotetext{
${ }^{5}$ Poviat (county) is the second-level of local government and administration in Poland, equivalent to county, district or prefecture in other countries.
} 
OECD states. This group is marked by a growing share of Asian states and a declining share of Eastern and South-Eastern European states.

The present volume of officially recorded long-term migration is the most often related to citizens of non-OECD states taking jobs in Poland. It is estimated at approx. 20,000-30,000 persons annually. The duration of immigrants' stay on Poland's labour market is another issue. Owing to the lack of suitable data, it is difficult to assess what part of the annual immigration stream returns to their country of origin or leaves for another state after a lapse of time (regardless of whether such a decision is of personal nature or results from a worker being posted).

\subsection{Citizens of Ukraine, Russia and Belarus undertaking temporary employment in Poland.}

Polish employers strongly opted for a possibility to employ seasonal workers originated from foreign countries. In consequence, in 2007 the government decided to introduce a pilot programme on temporary employment ${ }^{6}$ targeted at citizens of Ukraine, Belarus and Russia (Moldova joined the programme in 2009). Currently, an employer who wishes to employ a foreign worker from Ukraine, Belarus or Russia (maximum employment period is six months within a year) has to complete a declaration at a Poviat Employment Office. Following that declaration, a foreign worker obtains the right to receive a residence visa with work permit for an employment period not exceeding six months. Over 600,000 declarations were registered in Poviat Employment Offices from the implementation of the pilot programme between July 2007 and December 2009. In 2007 the number of declarations was slightly higher than 23,000, while in 2008 the number of registered declarations exceeded 150,000. In 2010, around 190,000 declarations were registered. In 2011 we observe a significant increase in the number of declarations. The first six months data show more than 160,000 new declarations. This means that for the entire year the number of them will approach around 250,000. However, registration of a declaration does not mean that employment is actually undertaken. Employment monitoring shows that around 70 per cent of registered declarations leads to issuing a visa followed by undertaking employment in Poland.

\footnotetext{
${ }^{6}$ The pilot programme has been turned into a permanent regulation.
} 
Tab 2. The number of seasonal workers in 2007-2011 (the first half of the year).

\begin{tabular}{|ll|}
\hline 2007 & 23,284 \\
\hline 2008 & 156,105 \\
\hline 2009 & 189,317 \\
\hline 2010 & 180,073 \\
\hline 2011 & $\begin{array}{l}163,984 \text { (the first half of } \\
\text { the year) }\end{array}$ \\
\hline
\end{tabular}

Source: the Ministry of Labour and Social Policy

The above mentioned figures are not fully comparable with the official data on the number of declarations before the pilot programme was introduced The figures suggest strong influence of the changes for the scale of legalising the employment of immigrants from Poland's Eastern neighbouring countries. The largest number of declarations concerns intended employment of foreigners in agriculture and the construction industry. These two sectors are responsible for almost 75 per cent of all declarations. Other sectors include the hotel industry, catering and transport.

The analysis of the number of employers' declarations in terms of monthly arrangement confirms the thesis that temporary immigration to Poland is of a seasonal nature. Moreover, the minimum falls during autumn and winter months are followed by dynamic growth in the number of legally employed foreigners. Over 90 per cent of declarations are registered with the intention to give employment to citizens of Ukraine. Declarations for citizens of the Russian Federation are issued occasionally.

Based on the analysis of the collected declarations from employers a typical characteristic is: a Ukrainian male aged over 26, employed in agriculture or the construction industry. His/her employment is unlikely to be related to any intention to settle for longer, and the motivation for immigration is purely economic. 
Monitoring of the system of declarations registration leads to two simultaneous observations.

Firstly, the system of declarations of the intention to employ a foreigner worker on a temporary contract is effective. The system allows for adjusting the flow of foreign workers to the real demand of Polish companies. The growing number of declarations suggests the conclusion that introduction of the pilot programme reduced the scale of illegal employment of foreign temporary workers in Poland.

Secondly, lack of a control system over actual realisation of declarations can cause real problems, which may lead to use of the system for other purposes than employment of temporary workers. According to current regulations the following situation is likely: an employer reports the hire of a foreigner in an Employment Office appropriate for the location of the company but the employer is only an intermediary. The workers brought by the company are actually employed by other entities. Such mediation may also involve sending the temporary workers to other European Union countries. This is not reason enough to justify eradication of the declaration system. Nevertheless, it is necessary to supplement the system with information-provision obligations, whereby employers must give information on exactly when the worker commences and leaves employment.

\subsection{Regional diversification of employment of immigrants in Poland}

Based on statistical data and scientific research we can ascertain that the largest number of immigrants take up employment in Mazowieckie voivodeship ${ }^{7}$ (most likely in metropolitan Warsaw), followed by: Dolnoslaskie, Wielkopolskie, Malopolskie and Śląskie voivodeships (most likely in the following big Polish cities: Wroclaw, Poznan, Cracow and Upper Silesian towns). These most developed regions have the strongest economic activity, best-developed transportation system, social infrastructure as well as most modern economy structure. The regions surround fast developing urban agglomerations. At the same time the regions have stable demand for labour as well as the lowest unemployment rate.

\footnotetext{
${ }^{7}$ Voivodeship is a high-level administrative subdivision in Poland - region or province in other countries.
} 


\subsection{Foreign students in Poland}

15,319 foreigners studied in Poland in the academic year 2008/2009. ${ }^{8}$ For over 30 per cent of them this is their first year of study in Poland. Over 70 per cent of the students are citizens of European states. Other groups constitute citizens of Asian countries -17 per cent, the USA - 8 per cent and Africa - 5 per cent.

It is no surprise that in Poland over 20 per cent of students are of Polish origin. For instance this category of foreigners accounted for 85 per cent of students from Lithuania, 75 per cent from Kazakhstan and 49 per cent from Belarus. Foreigners of Polish origin from Germany and Russia (28 per cent each) and from Ukraine (25 per cent) also formed a relatively large group of students.

The largest nationality-based groups among foreign students studying in Poland are: Ukrainians (18 per cent) and Belarusians (12 per cent.). They are followed by Americans, Norwegians, Czechs and Swedes.

Without doubt the most popular discipline chosen by foreigners is medicine (almost 35 per cent), followed by economics ( 30 per cent) and administration (20 per cent). Another 14 per cent of the students chose social sciences, and 12 per cent liberal arts.

\section{Access of immigrants to the Polish welfare system.}

\subsection{Interaction between migration policy and social assistance}

Migration policy in Poland is divided in two parts, the coordination of which is entrusted to the Minister of Labour and Social Policy, and the Minister of the Interior and Administration, respectively. The Minister of Labour and Social Policy is responsible for issues regarding the opening of the Polish labour market for third country nationals and for integration policy. The Minister of the Interior and Administration is accountable for issues pertaining to visa policy, granting of the right to stay and for actions targeted at refugees. Unfortunately, analyses indicate that no direct relationship between these two parts is stipulated by Polish legislation in migration policy and foreigners' integration policy. Decisions made within migration policy do not entail any decisions concerning the integration policy or any changes in

\footnotetext{
${ }^{8}$ Data obtained from the Central Statistical Office, 2008/2009.
} 
the foreigners' access to the social security system. This situation results from the fact that the number of third country nationals residing permanently in Poland is very low and Poland receives mainly temporary workers.

As a rule, integration measures are not provided to temporary workers, nor do they guarantee access to the social security system. Statistics on the use of social security instruments show the share of foreigners to be marginal. Currently, under the auspices of the Minister of the Interior and Administration, intensive works are underway on defining a new migration strategy for Poland. ${ }^{9}$ One of the major political decisions to be reached is the necessity to develop very specific links between migration policy decisions and those dealing with an access of third country nationals to the social security system. The opening of the Polish labour market for foreigners should be accompanied by decisions concerning inclusion of third country workers into Polish society. They should ensure them access to selected social security instruments to avoid the risk of social exclusion. This issue is to remain in the competence of the Minister of Labour and Social Policy. The decision results from the binding migration policy doctrine which assumes the primacy of labour market needs, i.e. replenishment of emerging labour force shortages.

\subsection{The legal dimension of the integration of immigrants in Poland}

In Poland the Ministry of Labour and Social Policy is responsible for the development and coordination of foreign nationals' integration policy (here 'foreign' means mostly from non-OECD countries). The President of the Office for Foreigners is accountable for the granting refugee status to foreign nationals, supplementary protection or issuing a tolerated stay permit. At the same time practical assistance to foreign nationals who have problems integrating with Polish society is implemented in local governments at Poviat level. Poviat Family Assistance Centres provide immigrants with the following assistance i.e.: provision of social assistance and implementation of integration programmes, including individual integration programmes.

\footnotetext{
${ }^{9}$ At the end of September 2011 new migration strategy proposals were directed to the Council of Ministers.
} 
In Poland the issues on foreign nationals' integration are regulated by the Act on Social Assistance of $2004^{10}$ and the Act on Granting Protection to Foreigners on the territory of the Republic of Poland of 2003. ${ }^{11}$

The main aim of social assistance in Poland is to support individuals and families to overcome difficult life situations. It should be highlighted that only those individuals or families who are unable to overcome economic and social problems with their own powers, resources or capacities will be eligible for social assistance benefits.

According to the Act on Social Assistance, the right to social assistance benefits is enjoyed by foreigners with a place of residence and residing on the territory of the Republic of Poland pursuant to:

- $\quad$ settlement permit,

- residence permit for persons with long-term resident status of the European Community,

- temporary residence permit issued in connection with the circumstance referred to in Article 53, paragraph 1, section 13 of the Act on Foreigners of 13 June 2003 (a person who has a long-term resident permit of the EC granted by another member state of the European Union, or intends to work or carry out economic activity according to regulations in force in the Republic of Poland, takes up or continue studies or vocational training, or proves existence of other circumstances justifying his or her residence on the territory of the Republic of Poland),

- acquisition of refugee status or supplementary protection in the Republic of Poland,

- tolerated stay permit (only in the form of a shelter, food, necessary clothing and purpose benefit).

Moreover, according to the acquis communautaire, the right to social assistance is enjoyed by citizens of the member states of the European Union, member states of the European Free Trade Association - parties to the agreement on the European Economic Area or Swiss Confederation and members of their families.

\footnotetext{
${ }^{10}$ (O.J. of 2004 No. 64, item 593 as amended)

${ }^{11}$ (O.J. of 2003 No. 128, item 1176 as amended)
} 
The following groups of foreigners also enjoy the right to benefits in the form of crisis intervention, shelter, food, necessary clothing and purpose benefit:

- in the case when there is a reasonable suspicion that a foreigner is a victim of human trafficking in the understanding of the Council Framework Decision of 19 July 2002 on combating human trafficking (O.J. EC L 2003 of 1.08.2002), confirmed by the body competent to proceed in a case of combating human trafficking,

- is a victim of human trafficking in the understanding of the Council Framework Decision of 19 July 2002 on combating human trafficking and meets jointly the following conditions: stays on the territory of the Republic of Poland, entered into cooperation with a body competent to carry out proceedings in a case of combating human trafficking, interrupted contacts with persons suspected of committing forbidden acts related to human trafficking and in the situation when the circumstance constituting the basis for applying for such a permit justifies his or her residence on the territory of the Republic of Poland for a period longer than 3 months.

The Act on Social Assistance also contains a special chapter entitled "Social integration of third-country nationals who acquired refugee status or supplementary protection in the Republic of Poland". It includes provisions pertaining to the instruments applied in regards to the integration of foreign nationals in Poland and specifies institutions accounted for provision of assistance to foreign nationals. ${ }^{12}$

\subsection{Access to social assistance}

According to the Act on Social Assistance, foreign nationals staying in Poland legally have access to forms of support parallel to those available to Polish citizens. In recent years the most frequent forms of support included: provision of permanent benefit, purpose benefit, temporary benefit, special purpose benefit and family benefit.

\footnotetext{
${ }^{12}$ At the beginning of 2012 a proposal for the Aliens Act amendment is to be announced to the government. The Act will make many changes on the residence permit of foreign nationals in Poland. However, fundamental changes to the principles of foreign nationals' integration in Poland cannot be expected. Only amendments to the Act on Social Assistance may cause changes in this respect. However, this is not anticipated until the end of 2012.
} 
Foreign nationals who receive social transfers in Poland can be divided into four categories: citizens of the EEA states, third-country nationals with tolerated stay status in Poland, refugees and foreign nationals. Statistics on support provision to various categories of foreigners are provided in Table 3.

Tab. 3: The total amount of social assistance benefits provided to various categories of foreign nationals in 2004-2010 in PLN.

\begin{tabular}{|c|c|c|c|c|c|c|c|c|}
\hline \multirow[t]{2}{*}{ Year } & \multicolumn{2}{|c|}{$\begin{array}{l}\text { Citizens of EEA } \\
\text { states }\end{array}$} & \multicolumn{2}{|c|}{$\begin{array}{ll}\text { Immigrants } & \text { with } \\
\text { tolerated } & \text { stay } \\
\text { status } & \end{array}$} & \multicolumn{2}{|c|}{$\begin{array}{lr}\text { Refugees } & \text { after } \\
\text { completion of an } \\
\text { individual } \\
\text { programme } \\
\text { integration }\end{array}$} & \multicolumn{2}{|c|}{$\begin{array}{l}\text { Third-country } \\
\text { nationals }\end{array}$} \\
\hline & Amount & $\begin{array}{c}\text { Numbe } \\
r\end{array}$ & Amount & $\begin{array}{c}\text { Numbe } \\
r\end{array}$ & Amount & Number & Amount & Number \\
\hline 2004 & $\begin{array}{c}28,184.7 \\
0\end{array}$ & $\begin{array}{c}43 \\
\text { persons }\end{array}$ & $104,673.40$ & $\begin{array}{c}214 \\
\text { persons }\end{array}$ & $162,721.70$ & 99 persons & $\mathrm{N} / \mathrm{A}$ & N/A \\
\hline 2005 & $\begin{array}{c}25,546.6 \\
0\end{array}$ & $\begin{array}{c}23 \\
\text { persons }\end{array}$ & $164,073.30$ & $\begin{array}{c}308 \\
\text { persons }\end{array}$ & $163,914.90$ & $\begin{array}{c}162 \\
\text { persons }\end{array}$ & $356,188.29$ & $\begin{array}{c}595 \\
\text { persons }\end{array}$ \\
\hline 2006 & $\begin{array}{c}53,203.6 \\
8\end{array}$ & $\begin{array}{c}80 \\
\text { persons }\end{array}$ & $498,336.30$ & $\begin{array}{c}800 \\
\text { persons }\end{array}$ & $203,234.20$ & $\begin{array}{c}241 \\
\text { persons }\end{array}$ & $869,823.00$ & $\begin{array}{c}1094 \\
\text { persons }\end{array}$ \\
\hline 2007 & \multicolumn{2}{|c|}{$\mathrm{N} / \mathrm{A}$} & \multicolumn{2}{|c|}{ N/A } & \multicolumn{2}{|c|}{ N/A } & \multicolumn{2}{|c|}{ N/A } \\
\hline 2008 & $96,900.64$ & $\begin{array}{c}90 \\
\text { persons }\end{array}$ & $309,415.50$ & $\begin{array}{c}531 \\
\text { persons }\end{array}$ & $414,566.40$ & $\begin{array}{c}284 \\
\text { persons }\end{array}$ & $950,025.10$ & $\begin{array}{c}894 \\
\text { persons }\end{array}$ \\
\hline 2009 & 248,293 & $\begin{array}{c}157 \\
\text { persons }\end{array}$ & $192,151.70$ & $\begin{array}{c}285 \\
\text { persons }\end{array}$ & $271,223.20$ & $\begin{array}{c}236 \\
\text { persons }\end{array}$ & $\begin{array}{c}1,029,532 \\
00\end{array}$ & $\begin{array}{c}875 \\
\text { persons }\end{array}$ \\
\hline
\end{tabular}

Source: Own calculation based on statistics from the Ministry of Labour and Social Policy

To these figures we should add the immigrants who received supplementary protection in 2008 and 2009 (introduced to Polish law - 29 May 2008). The total amount of benefits provided to this category of immigrants equalled PLN 548,908.60 
for 808 beneficiaries in 2008 and $1,265,458.00$ for 2,160 in 2009 . This means that the amount of benefits from social assistance paid to immigrants staying legally in Poland not taking individual programmes of integration into account exceeded PLN 3 million (approx. EUR 750,000).

The analysis of data provided in the table indicates that both the number of foreigners taking advantage of social assistance in Poland and the amount of benefits paid have grown dynamically.

\subsection{Housing}

Access to housing is definitely most difficult problem for the integration of non-OECD foreign nationals in Poland. There is no data available on the places of residence of foreigners in Poland. The only available comparative data are constituted by information about refugees and immigrants who received supplementary protection and who participate in individual integration programmes. Moreover, information on provision of municipal housing provided to immigrants from resources of individual cities is collected within research programmes. The acquired data show that the number of municipal flats provided to immigrants on the scale of the entire country in 2000-2009 was little over 120, over half of which was in Warsaw. Municipal flats were most frequently provided to citizens of Russian Federation of Chechen origin.

Various data ${ }^{13}$ suggest that the largest number of immigrants rent flats on their own. Another large group chooses joint residence with family members and stay in refugee centres. Available data indicate that only a small group of immigrants could afford to acquire and hold a flat. Refugee centres are main places of residence in the case of refugees, immigrants with supplementary protection or with tolerated stay status. Owing to the location of such centres in Poland, this largely hinders social integration.

In Poland there is also one refugees' support centre called "Refugee House" run by the NGO - Polish Humanitarian Action. It provides 30 vacancies for immigrants who are in a particularly difficult situation.

Unfortunately, it is extremely difficult to find housing for immigrants, particularly those staying in Poland with refugee status or tolerated stay status. Research carried

\footnotetext{
${ }^{13}$ For example, data obtained from research of the Legal Intervention Association carried out among refugees and by the Institute of Social Policy University of Warsaw among various categories of immigrants.
} 
out by the Institute of Social Policy showed that the lessors set higher requirements for foreign lessees than for Polish citizens. This concerns, in particular, immigrants from African and Asian states, and often also immigrants from neighbouring countries, e.g. from Ukraine. ${ }^{14}$

\subsection{Camps for Refugees}

One of the fundamental forms of support for foreigners applying for refugee status or supplementary protection is to ensure them peaceful and decent conditions while waiting for the decision to be issued. Most frequently such foreigners are placed in refugee centres where for a certain transitional period they become acquainted with the specifics of the host country including essential information regarding Polish laws. Moreover, these centres offer integrating measures such as provision of information about their rights and obligations as well as Polish language teaching. It should be pointed out that placement of foreigners in the centres is dictated by two main factors, namely registration of their stay in the host country and lack of any alternative to resolve the problems of their homelessness.

Twenty refugee centres operate in Poland. ${ }^{15}$ Foreigners who obtain the right to stay in a centre are eligible for the following benefits:

- food;

- public transport tickets (to participate in proceedings for granting refugee status, to turn up for medical examinations, protective vaccinations or in other particularly justified cases),

\footnotetext{
${ }^{14}$ Results from the research project Altercamp carried out by the Institute of Social Policy, Warsaw University. For more details see: G. Firlit - Fesnak, Ł. Łotocki (ed.) "The situation of foreigners searching for protection in Poland - a report from FGls with foreigners residing in the refugee centre in Czerwony Bór" ("Sytuacja cudzoziemców poszukujących ochrony w Polsce - raport z zogniskowanych wywiadów grupowych z cudzoziemcami mieszkającymi w ośrodku dla uchodźców w Czerwonym Borze"), G. Firlit-Fesnak, Ł. Łotocki (ed.) "Local community and institutions towards the initiative of creation a refugee centre" ("Społeczność i instytucje lokalne wobec inicjatywy utworzenia ośrodka dla uchodźców"), J.Supińska, G.Firlit-Fesnak, Ł.Łotocki "Xenophobia in Europe. Forms of institutional, political and social discrimination" ("Ksenofobia w Europie. Formy dyskryminacji instytucjonalnej, politycznej oraz społecznej"), Migration Report No.2/2003, the Institute of Social Policy, Warsaw University.

${ }^{15}$ Data obtained from the Office for Foreigners.
} 
- teaching aids for children learning in public facilities, primary and secondary schools,

- permanent pecuniary assistance for purchase of personal hygiene products and to cover minor expenses,

- medical care

Moreover, foreigners placed in the centres can obtain:

- pecuniary assistance for food (children under 3, children attending schools and sick persons for whom the centres are unable to ensure a suitable diet),

- one-off assistance for purchase of clothes and footwear,

- free-of-charge Polish language teaching with basic teaching materials.

Approximately 3,000 persons were staying in the centres as of the end of 2009. Another 2,000 were staying outside the centres but took advantage of the possibility to obtain the financial assistance.

Analysis of the furnishing and living standards in the refugee centres in Poland show fundamental differences in this regard. Only a few centres offer high quality conditions that do not depart from standards of such places in other states receiving large quantities of refugees. Many centres are located in buildings previously occupied by the army and both the conditions and living standards are in need of urgent improvement. ${ }^{16}$

\subsection{Individual Programs of integration for refugees.}

The most common and extensive action aimed at integrating immigrants with Polish society is the Individual Programme of Integration. Initially, this instrument was targeted solely at foreigners who were granted refugee status. In the amendment to the Act on Granting Protection to Foreigners on the territory of the Republic of Poland of $2008^{17}$ the possibility of realising individual programmes of integration was extended to all foreigners who have been granted "supplementary protection". In

\footnotetext{
${ }^{16}$ See: M.Ząbek S.Łodziński Uchodźcy w Polsce. Próba spojrzenia antropologicznego. Warsaw 2008 ${ }^{17}$ O. J. 2008 , No. 70 , item 416
} 
practice this means that all foreigners who have been granted the right to legal stay on the territory of Poland (pursuant to acquisition of refugee status or supplementary protection) can currently participate in individual integration programmes. The introduced changes spurred a dramatic growth in the number of foreigners taking advantage of this form of support (see table No. 4).

The implementation rules for individual programmes of integration were regulated by the Act on Social Assistance and by the Regulation of the Minister of Labour and Social Policy of 20 March 2009. ${ }^{18}$ on provision of assistance to foreigners who have acquired refugee status or supplementary protection in the Republic of Poland. They concern in particular:

- the requirements foreigners must meet before support is granted to them (including: written commitment to active participation in the realisation of an individual programme of integration or declaration on the intention to reside on the territory of a voivodship, and - in the case of refugees - the official document granting such status),

- duration of the individual programme of integration (maximum of 12 months),

- the amount of pecuniary benefits allocated to subsistence in Poland and Polish language learning,

- free-of-charge access to health care services,

- the principles for granting practical support to foreigners (social work, legal and psychological counselling etc. as well as provision of support in contacts with labour market institutions, NGOs, and other institutions, contact with which can accelerate the process of integration into Polish society),

- obligations of the Poviat Family Assistance Centres (including provision of information, acting as a an intermediary in contacts with other institutions, management of social work, support in search for housing, appointing the employee responsible for daily contacts with foreigners),

- obligations of a foreigner during programme implementation (including registration in a Poviat Employment Office, meeting the formal requirements on registration of residence, obligatory participation in the Polish language

${ }^{18}$ O.J. of 2009 No. 45 item 366 
courses if the need arises, maintenance of permanent contacts with an employee of the Poviat Family Assistance Centre assigned to cooperate with a foreigner).

The individual support programme can also be realised by a household encompassing the spouse of a foreigner and dependent children provided they have received refugee status or supplementary protection in Poland.

The individual integration programme agreed between the Poviat Family Assistance Centre and the foreigner is transferred to the Voivod. ${ }^{19}$ The programme must include an appendix containing envisaged costs of the implementation thereof. Final acceptance of the programme is made by the Voivod, who submits it for execution.

As far as individual support programmes are concerned provision of support to foreigners in search of housing is a very interesting but at the same time controversial instrument The final decision regarding the choice of abode of a foreigner is made by the Voivod who should take into account the foreigner's preferences or proposals in this regard. Waiver of the place of residence agreed with the Voivod during the programme's duration results in interruption of the programme. A change in this respect is possible only in particularly justified cases, such as taking up work entailing the necessity to reside in a different place or in the case when it becomes possible to reside jointly with other family members. It is also possible when a foreigner needs to obtain specialist medical assistance. In such cases deployment of an individual support programme is taken over by the poviat of the new location of foreigner's abode.

Interruption of the individual integration programme takes place e.g. in the situation of persistent failure on the part of a foreigner to meet the commitments assumed in the programme (e.g. unjustified absence at the Polish language course exceeding 30 days), provision of false information, fraudulent spending of received aid and issue of penal proceedings against the foreigner.

In accordance with the Act and Regulation, support in the process of integration is provided to foreigners on the basis of an assessment of their own and their families' life situation. The primary effect of the individual support programme is to be produced by the foreigner's integration on the local labour market (becoming

\footnotetext{
${ }^{19}$ Governor of a province.
} 
economically self-dependent) and initiation of permanent contacts with the local community. They are measured by the degree of participation in social, cultural and public life. Another important indicator showing integration progress is linguistic education, particularly as regards acquisition of phrases and vocabulary enabling ease of communication with Poles.

As already mentioned, extension of the categories of foreigners who may benefit from individual integration programmes in 2008 and 2009 caused a sharp increase in the number of foreigners covered. While in 2004 the number of such programmes deployed on the territory of Poland amounted to 167, in 2008 there were already 698 such programmes $(99$ for refugees and 598 for foreigners who were granted supplementary protection) and in $2009-1,443$ programs (102 for refugees and 1,341 for foreigners who were granted supplementary protection). Table 2 provides details.

In 2009 4,065 foreign nationals took part in individual integration programmes. Among them 3,912 were Russian Federation citizens of Chechen origin.

The figures provided in Table 2 suggest Russian Federation citizens of Chechen origin prevail among beneficiaries of individual integration programmes in Poland. The share of representatives of other states or nations is marginal. The domination of Chechens is suggested by the data from the Office for Foreigners. The data show that representatives of this nation obtain the largest number of refugee or supplementary protection status decisions.

Table 2. Individual integration programmes

\begin{tabular}{|l|c|l|}
\hline Year & $\begin{array}{c}\text { Number of } \\
\text { programmes }\end{array}$ & Main beneficiaries (families) \\
\hline 2004 & 167 & $\begin{array}{l}\text { Chechnya (139), Belarus (8), Pakistan, Somalia } \\
\text { (3 each) }\end{array}$ \\
\hline 2005 & 196 & Chechnya (160), Somalia (12), Iran (5) \\
\hline 2006 & 244 & Chechnya (218), Belarus (14), Iran (4) \\
\hline 2007 & 211 & N/A \\
\hline 2008 & 698 & $\begin{array}{l}\text { Chechnya (628), Afghanistan (13), Belarus } \\
\text { (12), Sri Lanka (11) }\end{array}$ \\
\hline 2009 & 1,443 & $\begin{array}{l}\text { Chechnya (1358), Afghanistan (12), Belarus } \\
\text { (16), Sri Lanka (17) }\end{array}$ \\
\hline
\end{tabular}

Source: Own data processing on the basis of the statistics from the Ministry of Labour and Social Policy 
The increase in the number of individual integration programmes is accompanied by a rise in the amount of funding spent on their implementation. In 2000 this amount equalled PLN 133,840 (approximately EUR 32,000), rising in 2008 to PLN 4,466.436 (approximately EUR 1.1 million) and in 2009 to 16,456.422 (approximately EUR 4 million). ${ }^{20}$

Chart 1. Cost of implementation of individual integration programmes in 2000-2008

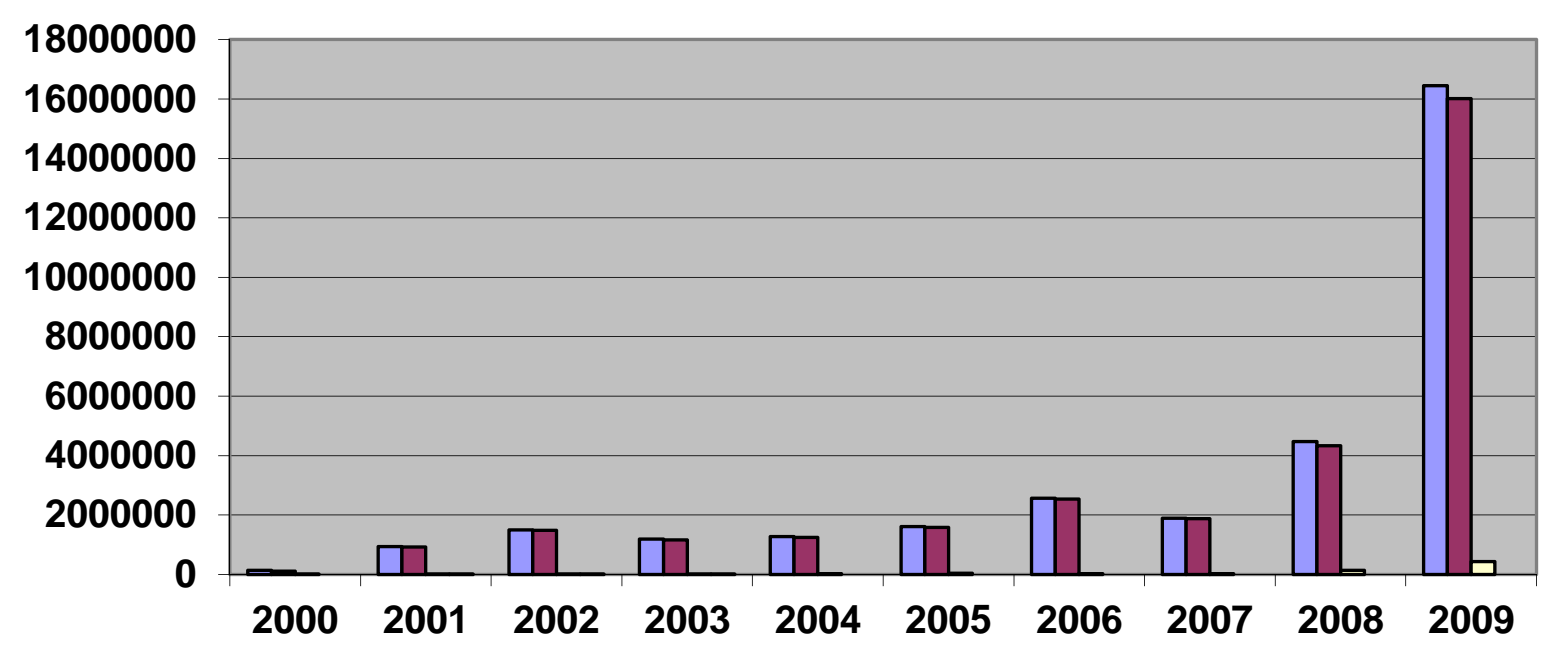

口Total $\square$ spending on subsistence $\square$ spending on language courses $\square$ others

Source: Own data processing on the basis of the statistics from the Ministry of Labour and Social Policy.

The chart above indicates that the vast majority of benefits granted within individual integration programmes were expended on costs related to subsistence. Only a marginal portion (less than 1 per cent) was spent on learning Polish or other integration measures. The sole exception was 2008, when approximately 3 per cent of all funds were spent on language courses.

The largest number of individual integration programmes has been implemented in Mazowieckie voivodship, followed by Podlaskie and Lubelskie voivodships. Regional diversification in the implementation of individual integration programmes reflects the places of stay of the majority of foreigners residing in Poland.

\footnotetext{
${ }^{20}$ These amounts do not cover expenditure related to activities of Poviat Family Assistance Centres, including the cost of realisation of welfare work, legal or psychological counselling or support in contacts with other institutions.
} 
Presently, the government is not planning to create other integration instruments targeted at broader groups of foreigners staying in Poland. In the opinion of the Ministry of Labour and Social Policy, inflow of foreigners to Poland is a new and poorly investigated phenomenon. Thus, before new instruments are introduced or the list of the beneficiaries of individual integration programmes is extended, it is necessary to study a real demand for integration actions in Poland. ${ }^{21}$

\subsection{Access of immigrants to the Polish education system.}

One of the key issues in the integration policy is to allow children of foreign nationals residing in Poland to use the education system. In general, a foreign national who is a legal resident on the territory of Poland has the same rights of access to the Polish education system as any Polish citizen. Poland's compulsory education covers all children residing on Polish territory. This means that there is a necessity to guarantee foreign nationals the right to education on equal terms with Polish citizens and impose on foreigners an obligation to send their children to school. The foreign nationals, being subject to compulsory education, shall have free access to Polish language tuition.

\subsection{Programs of NGOs for refugees and for immigrants with tolerated stay status.}

Although the issue of the integration of foreigners remains marginal, there are at least a dozen NGOs in Poland that aim to support foreigners' integration with Polish society. Their activities mainly apply to refugees and persons who have been granted supplementary protection or tolerated stay status in Poland, i.e. those staying in Poland legally. Simultaneously, there are organisations that provide support, usually legal, to foreigners whose stay in Poland is undocumented. The vast majority of them operate in Warsaw or its surroundings, i.e. in the region with the largest number of both legal and undocumented immigrants.

\footnotetext{
${ }^{21}$ Reply from a secretary of state in the Ministry of Labour and Social Policy, Jarosław Duda, to a parliamentary interpellation No. 2067 concerning individual integration programmes for refugees.
} 
The NGOs major initiatives are support for foreigners learning Polish and organisation of vocational courses. Thus, they bridge the gap that results from distribution of financing in the framework of individual integration programmes. The programmes address issues on daily subsistence needs.

The Polish Humanitarian Action and the Centre for Assistance to Refugees (operating since 1993) are the best known organisations that support refugees and other immigrants staying legally in Poland. The Centre provides legal counselling to persons who have already obtained refugee status, supplementary protection or tolerated stay status as well as to those foreigners who are in the process of applying for such status. Moreover, within the Centre for Assistance to Refugees two community centres for refugees (in Warsaw and in Linin near Warsaw) operate. The centres aim to accelerate the process of integration with Polish society through such activities as training, workshops and Polish language courses.

Another initiative of the Centre for Assistance to Refugees is a Labour Club. Its help desk specialists (vocational advisors and intermediaries) are available on call and assist foreigners in their search for employment. The Labour Club receives job offers from employers who agree to hire foreigners legally employable in Poland. It also cooperates with public employment services.

The major problem faced by NGOs running programmes for foreigners is financing. Owing to the rules governing the financing support programmes, they usually have a short term perspective of approximately 1 year. This causes confusion and makes it difficult for an organisation to specialise in professional assistance for foreigners.

Results of empirical research carried out among organisations supporting foreign nationals in their integration into the Polish society also confirm that state of affairs. According to that results, fragmentation of funds available causes unjustified competition among the organisations, which in turn leads to dispersion of their activities and also lack of cooperation. Non-governmental organisations opt for combining various sources of funds into a single fund for integration of foreign nationals. $^{22}$

\footnotetext{
22 Pawlak P, Szelewa D, Polakowski M, Fijałkowska M, Bąbiak I. (2010), (Dez) Integration Policy Management of integration of third countries citizens in Poland (Polityka (dez) integracji zarządzanie integracją obywateli państw trzecich w Polsce), Scholar, Warsaw p. 19.
} 
Owing to the low level of public interest regarding issues related to integration of immigrants staying in Poland, neither individual local governments nor donors are interested in increasing funds allocated for programmes targeted at foreigners. This situation is most likely to change with the expected increase in the number of the foreigners from culturally different regions of the world. They are to come and reside in Poland (including those coming in order to be reunited with their family) and they will need integration programmes.

A much greater problem for NGOs is constituted by support for undocumented foreigners staying in Poland illegally. As far as victims of human trafficking staying in Poland illegally, it is possible to legalise their stay, provided that they cooperate with law enforcement bodies and the judicature. The situation differs in the case of e.g. foreigners illegally employed in Poland. They are offered legal support on legalisation of their stay and assistance in the situation of threat to fundamental civil rights (e.g. exploitation by employers). The assistance is provided by Trade Unions and the Citizens Advice Bureau (which) focuses on a widely understood legal assistance).

Table 5. Forms of support to foreigners offered by selected Polish NGOs

\begin{tabular}{|l|c|c|c|c|c|c|c|c|c|c|c|}
\hline Organisation & 1 & 2 & 3 & 4 & 5 & 6 & 7 & 8 & 9 & 10 & 11 \\
\hline The Centre for Assistance to Refugees & X & x & x & x & x & x & x & X & X & x & X \\
\hline The Helsinki Foundation for Human Rights & X & & & & & & & & & & X \\
\hline The Association for Legal Intervention & X & & & & & & & & x & X \\
\hline Multicultural Occupational Adaptation Centre & & & & $\mathrm{x}$ & $\mathrm{x}$ & & & & $\mathrm{X}$ & & \\
\hline Legal Guidance of Warsaw University & $\mathrm{X}$ & & & & & & & & & \\
\hline The Legal Assistance Centre - Kraków & $\mathrm{x}$ & & & & & & & & $\mathrm{x}$ & $\mathrm{x}$ \\
\hline Legal Clinic of the Jagiellonian University & $\mathrm{X}$ & & & & & & & & & & \\
\hline Caritas & & $\mathrm{x}$ & & & $\mathrm{x}$ & & & $\mathrm{x}$ & & & \\
\hline IOM & & & & $\mathrm{x}$ & & $\mathrm{x}$ & & & & & $\mathrm{X}$ \\
\hline The Migrant Centre & & $\mathrm{x}$ & & & $\mathrm{x}$ & $\mathrm{x}$ & & $\mathrm{x}$ & $\mathrm{X}$ & & \\
\hline Polish Migration Forum & & & & & & & & $\mathrm{x}$ & $\mathrm{X}$ \\
\hline
\end{tabular}

1-legal assistance, 2-social counselling, 3-housing assistance, 4-support on the labour market, 5-psychological assistance, 6-Polish language learning, 7-foreign language learning, 8-assistance for children, 9-computer courses, 10-education, 11-lobbying for refugees.

Source: A. Kosowicz, A. Maciejko "Integration of refugees in Poland in figures" (“Integracja uchodźców w Polsce w liczbach"), Polish Migration Forum, Warsaw 2007. 
The NGOs also conduct numerous studies and social projects. The initiatives serve to make people aware of the advantages of integrating foreign nationals into Polish society, and broaden the decision makers' knowledge on principles of effective integration. Thus, the NGOs extort the right decisions from these decision makers. For example, in 2009-2010 the Legal Integration Association conducted the program "Neighbors or intruders -a study on discrimination of foreign nationals in Poland" whose aim was, among others, to write recommendations regarding integration policy for government authorities. Another interesting project is the portal www.migrant.info.pl that offers comprehensive information on the rules of stay in Poland, including availability of integration programs.

\subsection{European Fund for the Integration of Non-EU nationals.}

As a member state of the European Union, Poland receives financial resources from the European Fund for the Integration of foreign nationals. Its present edition is implemented in 2007-2013. The fund finances mainly pilot programmes addressed to both the foreigners who have obtained refugee status and those with supplementary protection or tolerated stay status. Activities financed from the fund are divided into two periods:

- 2007-2010 - research work and the development of a concept framework for integration processes in Poland on the building of an institutional system and action targeted at migrants and the host society.

- 2011-2013 - use of acquired knowledge about the process and further development of action improving awareness and integration addressed to migrants.

Poland adopted four priorities from the framework of the European Fund for the Integration of non-EU nationals:

- Implementation of action developed with a view to putting into effect the "Common basic principles for immigrant integration policy in the European Union"

- Development of evaluation indicators and methodology enabling assessment of progress and adjustment of policies and measures, as well as those facilitating process coordination of learning through comparison. 
- The creation of capacities for pursuance of proper policy, coordination and building intercultural competence in the member states at various levels of authority and in various ministries.

- Exchange of experience, good practice and information concerning integration between member states.

The total amount available for Poland from the Fund for 2007-2013 equals approximately EUR 15,610.000. Part of these funds is allocated for the integration programmes of which implementation the Ministry of Labour and Social Policy is accountable.

\subsection{European Fund for Refugees (2008-2013)}

Similarly to the European Fund for the Integration of Non-EU Nationals, Poland is eligible for support from another fund of that kind, namely the European Fund for Refugees (2008-2013). It aims to support actions taken by the member states and to encourage them to undertake efforts relating to the reception of refugees and displaced persons and to suffer the related consequences. Poland can obtain support of almost EUR 12 million for 2008-2013.

Poland has adopted the following priorities for the utilisation of funding:

- Improvement of reception conditions for foreigners applying for refugee status as well as development and improvement of the integration offer targeted at foreigners applying for refugee status.

- Improvement of the asylum procedure efficiency.

- Training of domestic entities on the procedure of granting refugee status as well as developing the linguistic and inter-cultural skills of the staff.

- Development and improvement of the integration offer for refugees and other categories of persons covered with international protection.

- Independent assessment of Polish procedures regarding proceedings of granting refugee status and methods for their improvement. 
- Familiarisation with the practices of other states in applying European instruments concerning international protection and exchange of experience in this respect.

- Actions, including those taken jointly with representatives of other European Union states, aiming to increase resources,

- Verify information about countries of origin and improve access to information sources; actions for expansion and improvement of the national system concerning information about countries of origin; the establishment of a database on pursued proceedings for refugee status.

Major programme beneficiaries include: the Office for Foreigners, Mazowsze Voivod, and NGOs.

\subsection{Pension system reform}

Social security systems are being reformed throughout Europe as well as in many non-European countries. These reforms are inevitable but their final shape is still subject to discussion. We do not know what the systems will look like in the future. For the time being they most often work in what might be called the "traditional" way which means there are some problems regarding portability of rights. That of course affects the situation of legally residing and working migrants.

Poland has simply applied European rules in this respect. However, a very profound pension reform has already been implemented in Poland. ${ }^{23}$ In the context of this study this means a better situation of foreign workers who - if legally employed will not lose anything of their contribution to the system even if they work in Poland for a short time.

The new retirement pension system is based on two types of individual accounts. Legally employed workers pay 19.52 per cent of their wages/salaries to the accounts. The entire contribution is split between two accounts (12.22 per cent flows through the first account; 7.3 per cent through the second one). Account values (in both accounts) are transformed into annuities. In the case of foreign workers the account values will probably be relatively small, which will cause simplified pay-outs from the

\footnotetext{
${ }^{23}$ The reform concerned the retirement part of the pension system. Other parts of social security have not been reformed in the same way yet.
} 
system as in the case of Polish workers having very small account values. There is no vesting period. Each zloty paid to the system as a contribution (however, only the retirement contribution) plus the rate of return earned will come back to the worker. Only the minimum pension level guarantees a certain period of registered employment. ${ }^{24}$ Consequently, periods of work in Poland count for acquiring retirement pension rights irrespective of any characteristic of the employment but its legal status comes within the immigrant friendly social security framework.

\subsection{Foreigners and natives in the welfare system}

In 2008 Poland paid almost 225,000 unemployment benefits, and almost 3,800,000 family benefits. Unfortunately, it is impossible to obtain information on what percentage of them was granted to foreigners. Polish statistics do not take such information into account. At the same time it must be stated clearly on the basis of social research, that the share of foreigners receiving social benefits is marginal, because so far foreigners have not used the social security system excessively, a phenomenon which is typical of other European states. The only marked phenomenon in this respect is the use by children of foreigners staying in Poland supplementary classes in schools, which aim to help bridge the educational gaps resulting from an inadequate command of the Polish language. Data from the Ministry of National Education suggest that this is not a problem for Polish schools.

\section{Conclusions and recommendations}

The effective integration of foreigners is one of key elements to successful immigration policy. Experience of many immigration states have shown that a lack of an effective integration policy leads to a change of social attitudes towards foreigners from tolerant to hostile. This has led to many social conflicts and a rise in xenophobic attitudes in many European Union countries that have recorded an increased inflow of foreigners in recent years.

In the case of Poland the issue of the integration of foreigners is not an acute problem as yet, since the scale of inflow remains small and Poland is more often

\footnotetext{
${ }^{24}$ This means 30 years for women and 35 years for men during which they pay contributions from at least the minimum wage.
} 
treated as a transit country or a place of temporary employment. It must be assumed, however, that as Poland transforms from a typical emigration country into an emigration-immigration one, the scale of inflow of permanent immigrants will gradually increase. But it needs to be assumed that e.g. due to an absence of colonial traditions, Poland is unlikely to show dramatically increased settlement of foreigners in the time perspective of the next dozen years.

We should assume that command of language and access to the labour market are two key elements for avoidance of social tension and for effective incorporation of foreigners into Polish society, translating into a successful integration policy in Poland. These two measures aim to find a compromise between the adaptation process and assimilation of foreigners into Polish society.

It seems that the existing integration policy should be changed towards increased effectiveness of the applied labour market policy instruments, even if the adjustment of a foreigner to the requirements of the Polish labour market proves to be a long process. But we must be aware that, owing to the transit nature of Poland, many foreigners are not interested in integration in Poland. This fact should be taken into account, although it should not form the main assumption of Polish integration policy. It is of importance, however, to make a broad range of instruments available to those foreigners who display willingness to integrate within Polish society.

It is worth noting that the integration policy pursued in Poland is fundamentally targeted only at refugees and persons covered with supplementary protection. In the case of other groups of foreigners, it is true that they have access (in the cases listed in the Act on Social Assistance) to social assistance, but it is hard to deem this fact as sufficient for ensuring the effective integration of foreigners into Polish society. The list of actions and instruments targeted at integration into the labour market should definitely be expanded.

It seems that the experience of many immigration states points to the necessity of providing integration programmes not only to refugees, persons covered by supplementary protection or those with tolerated stay status, but also those foreigners who have obtained a permit to stay in Poland pursuant to other premises, and citizens of other member states of the European Economic Area coming to Poland. This also concerns persons coming to Poland in order to reunite with their family or to marry Polish citizens. It is necessary to balance obligatory participation in integration programmes with integration measures which foreigners could take advantage of on a fully voluntary basis. 
Individual programmes of integration, which currently cover refugees and persons with supplementary protection, must be definitely more flexible than they are now. As an example one might consider dividing them into stages. Transition to the next stage should be dependent on a progress towards integration. At the first stage, foreigners should learn about Poland as a host country and this should be combined with intensive learning of the Polish language. The next stage should consist of support in acquisition (supplementation) of the qualifications that might be used on the Polish labour market. So-called monitored employment should follow the third stage. As a result of the final stage, a foreigner or the entire household should become self-dependent. It is worth considering suspension of integration if there is no progress. The question remains, however, what sanction should be applied for removal from the integration programme.

Simultaneously, despite very scant experience in the field of foreigners' integration, elements that must be assessed positively include the improved offer of Polish language courses for foreigners, and activities of NGOs receiving grants from government and local government institutions. It must be stressed, however, that due to marginal use of integration policy instruments and social security by foreigners, it would be premature to state unanimously to what extent individual actions meet their target and fulfil their tasks.

\section{References}

1. Balicki J., Stalker P. (2006) Immigration and asylum policy, challenges and dilemmas (Polityka imigracyjna i azylowa, wyzwania i dylematy), Warsaw.

2. Bieniecki M., Kaźmierkiewicz P, Smoter P. (2006) Integration of foreigners in Poland. Selected aspects (Integracja cudzoziemców w Polsce. Wybrane aspekty), the Institute of Public Affairs, Warsaw.

3. Data from the Office for Foreigners concerning proceedings pursued towards foreigners for the years 2005 2010, http://www.udsc.gov.pl/Zestawienia,roczne,233.html

4. Duszczyk, M., Korczyńska, J., (2005), Demand for foreigners' work in Poland. An attempt at an analysis and conclusions for migration policy 
(Zapotrzebowanie na pracę cudzoziemców w Polsce. Próba analizy i wniosków dla polityki migracyjnej), Warsaw.

5. Duszczyk M., Szylko-Skoczny M. (2009) The report of the Institute of Social Policy about the scale of employment immigration to Poland developed for the Ministry of Labour and Social Policy, Warsaw, duplicated typescript

6. Górny A, Grzymała-Kazłowska A, Kępińska E, Fihel A, Piekut A (2007) From collective to community: the role of settling migrants in the creation of immigrant communities in Poland (Od zbiorowości do społeczności: rola migrantów osiedleńczych w tworzeniu się społeczności imigranckich w Polsce), CMR Working Papers, Migration Work Series 27 (85), the Centre of Migration Research, Warsaw

7. Grzymała-Kazłowska A. (ed.) (2008) Between unity and multitude. Integration of diverse immigrant groups and categories in Poland (Między jednością a wielością. Integracja odmiennych grup i kategorii imigrantów w Polsce). The Centre of Migration Research, Warsaw

8. Firlit-Fesnak G, Łotocki $Ł$ (ed.) (2007) The situation of foreigners searching for protection in Poland - a report from FGls with foreigners residing in the refugee centre in Czerwony Bór. (Sytuacja cudzoziemców poszukujących ochrony w Polsce - raport z zogniskowanych wywiadów grupowych z cudzoziemcami mieszkającymi w ośrodku dla uchodźców w Czerwonym Borze). Migration report No. 8/2007, Warsaw. www.ips.uw.edu.pl

9. Firlit-Fesnak G, Łotocki $Ł$ (ed.) (2006) Local community and institutions towards the initiative for creation of a refugee centre (Społeczność i instytucje lokalne wobec inicjatywy utworzenia ośrodka dla uchodźców). Migration report No. 7/2006, Warsaw. www.ips.uw.edu.pl

10. Grabowska-Lusińska, I., Żylicz, A., (ed.), (2008), Does the Polish economy need foreigners? (Czy polska gospodarka potrzebuje cudzoziemców?), The final report of Module II of MPLM project, the Centre of Migration Research, Warsaw University, 2008.

11. Information about the size and directions of emigration from Poland in the years 2004-2010 (Informacja o rozmiarach i kierunkach emigracji z Polski w latach 2004 - 2010), (2011), the Central Statistical Office, Warsaw. 
12. Information about research on immigration resources in Poland in 2008 (Informacja o badaniach zasobów imigracyjnych w Polsce w 2008), (2008), the Central Statistical Office, Warsaw.

13. International Organization for Migration (2003), Integration of Migrants: The IOM approach, Geneva.

14. Klaus W. (ed.) (2006) Legal determinants of the integration of refugees in Poland. A commentary for practicioners (Prawne uwarunkowania integracji uchodźców w Polsce. Komentarz dla praktyków), Warsaw.

15. Kosowicz A, Maciejko A. (2007) Integration of refugees in Poland in figures (Integracja uchodźców w Polsce w liczbach), Polish Migration Forum, Warsaw.

16. Pawlak P, Szelewa D, Polakowski M, Fijałkowska M, Bąbiak I. (2010), (Dez) Integration Policy - Management of integration of third countries citizens in Poland (Polityka (dez) integracji - zarządzanie integracją obywateli państw trzecich w Polsce), Scholar, Warsaw.

17. Reply from the secretary of state in the Ministry of Labour and Social Policy, Jarosław Duda, to the parliamentary interpellation No. 2067 concerning individual integration programmes for refugees. (2009). www.sejm.gov.pl

18. Supińska J, Firlit-Fesnak G, Łotocki Ł. (2003) Xenophobia in Europe. Forms of institutional, political and social discrimination („Ksenofobia w Europie. Formy dyskryminacji instytucjonalnej, politycznej oraz społecznej”), Migration Report No.2/2003, the Institute of Social Policy of the Warsaw University.

19. Yearbook of the Central Statistical Office 2004, 2005, 2006, 2007, 2008, 2009

20.Ząbek M. Łodziński S. (2008) Refugees in Poland, An attempt at an anthropological view. (Uchodźcy $w$ Polsce. Próba spojrzenia antropologicznego). Warsaw. 